\title{
Mixed-Ligand Nickel(II) Complexes Containing Sulfathiazole and Cephalosporin Antibiotics: Synthesis, Characterization, and Antibacterial Activity
}

\author{
J. R. Anacona and Maried Lopez \\ Departamento de Química, Universidad de Oriente, Apartado Postal 208, Cumana, Venezuela \\ Correspondence should be addressed to J. R. Anacona, juananacona@hotmail.com
}

Received 30 November 2011; Revised 13 February 2012; Accepted 24 February 2012

Academic Editor: Peter Baran

Copyright $\odot 2012$ J. R. Anacona and M. Lopez. This is an open access article distributed under the Creative Commons Attribution License, which permits unrestricted use, distribution, and reproduction in any medium, provided the original work is properly cited.

Nickel(II) reacts with cephalosporins plus sulfathiazole (Hstz) to form the following mixed-ligand complexes of general formulae $\left[\mathrm{Ni}(\mathrm{L})(\mathrm{stz})\left(\mathrm{H}_{2} \mathrm{O}\right)_{x}\right]_{n}\left(\mathrm{~L}_{1,4}, x=1 ; \mathrm{L}_{2,3}, x=0 ; \mathrm{L}=\right.$ monoanion of cefazolin $\mathrm{HL}_{1}$, cephalothin $\mathrm{HL}_{2}$, cefotaxime $\mathrm{HL}_{3}$, ceftriaxone $\left.\mathrm{HL}_{4}\right)$ and $\left[\mathrm{Ni}\left(\mathrm{L}_{5}\right)(\mathrm{stz})\right] \mathrm{Cl}$ (cefepime $\mathrm{L}_{5}$ ), which were characterized by physicochemical and spectroscopic methods. Their spectra indicated that cephalosporins are acting as multidentate chelating agents, via the lactam carbonyl and carboxylate and Nazomoieties. The complexes are insoluble in water and common organic solvents but soluble in DMSO, where the $\left[\mathrm{Ni}\left(\mathrm{L}_{5}\right)(\mathrm{stz})\right] \mathrm{Cl}$ complex is $1: 1$ electrolyte. They probably have polymeric structures. They have been screened for antibacterial activity, and the results are compared with the activity of commercial cephalosporins.

\section{Introduction}

Cephalosporins are classed as $\beta$-lactam antibiotics, and they are widely used in clinical therapy for the treatment of severe infections, because of their antibacterial activity $[1,2]$. Most common among several mechanisms by which bacteria develop resistance to $\beta$-lactam antibiotics is by elaboration of the enzyme $\beta$-lactamase, which hydrolyzes the $\beta$-lactam ring. A second mechanism is through alteration of penicillin-binding proteins (PBPs), which are found as both membrane-bound and cytoplasmic enzymes that catalyze cross-linking reactions in bacterial cell wall synthesis $[3,4]$. PBPs are targets of $\beta$-lactam antibiotics, which interfere with cell wall synthesis by binding covalently to the catalytic site. Most bacterial species produce several PBPs, differing in molecular weight, affinity for binding $\beta$-lactam antibiotics, and enzymatic function (e.g., transpeptidase, carboxypeptidase, or endopeptidase). The PBPs are usually broadly classified into high-molecular-weight and low-molecularweight categories $[3,4]$.
Prior to the availability and application of antibiotics for the control of diseases, sulfonamides were employed as effective chemotherapeutic agents for the prevention and cure of bacterial infections in humans $[5,6]$. Certain microbes require p-aminobenzoic acid (PABA) in order to synthesize dihydrofolic acid, which is required to produce purines and ultimately nucleic acids. Sulfonamides, chemical analogs of PABA, are competitive inhibitors of dihydropteroate synthetase. The complex formation between metal ions and sulfa drugs has also been extensively studied with a view to establish the relationship and importance of metal-drug interactions [7-10].

The interaction of antibiotics with main and transition metal ions has attracted our attention and compelled us to combine their chemistry in order to establish whether complexation affects the pharmacological properties of the ligand and to derive additional fundamental knowledge about antibiotic action [11-16]. We report here the synthesis, characterization, and antibacterial activity of nickel(II) complexes containing both sulfathiazole and cephalosporins ligands, in order to combine their antibacterial activities. The 
chemical structures of the ligands studied in this paper are shown in Figure 1.

\section{Experimental}

2.1. Physical Methods. All chemicals of reagent grade were commercially obtained from either Aldrich or Sigma and used without further purification. Solvents were redistilled by standard techniques before use. IR spectra were recorded as $\mathrm{KBr}$ pellets in the $4000-400 \mathrm{~cm}^{-1}$ range with a PerkinElmer Series 2000 FT-IR spectrophotometer. The electronic spectra of $1 \times 10^{-3} \mathrm{M}$ in DMSO solution of the ligand and its complex were recorded in the UV-Vis. region using a Shimadzu UV-240 spectrophotometer. The diffuse reflectance spectra of all the complexes in the $360-850 \mathrm{~nm}$ region were recorded on the same instrument equipped with a spherical reflectance assembly using $\mathrm{BaSO}_{4}$ as reference. $\mathrm{C}, \mathrm{H}, \mathrm{N}$, and $\mathrm{S}$ were analyzed on a LECO CHNS 932 model microanalytical instrument. Nickel contents were estimated with a PerkinElmer atomic absorption spectrophotometer. The halogen content was determined by combustion of the solid complex $(30 \mathrm{mg})$ in an oxygen flask in the presence of a $\mathrm{KOH}-$ $\mathrm{H}_{2} \mathrm{O}_{2}$ mixture. The halide content was then determined by titration with a standard $\mathrm{Hg}\left(\mathrm{NO}_{3}\right)_{2}$ solution using diphenyl carbazone as an indicator. Thermograms were recorded on a simultaneous thermal analyzer, STA-6000 (Perkin Elmer) instrument at a heating rate of $4^{\circ} \mathrm{C} \mathrm{min}{ }^{-1}$. Magnetic susceptibilities were measured on a Johnson Matthey Susceptibility Balance at $298 \mathrm{~K}$. The effective magnetic moments were calculated from the expression $\mu_{\text {eff }}=2.828\left(\chi_{M} T\right)^{1 / 2}$ B.M., where $\chi_{M}$ is the molar susceptibility corrected using Pascal's constants for diamagnetism of all atoms in the compounds. ESR spectra of the copper complexes were recorded on a JEOL microwave unit, JES-FE2XG Spectrophotometer. The magnetic field was calibrated with 2,2-diphenyl-1picrylhydrazyl.

2.2. Antibacterial Activity Tests. Antibacterial activities of cephalosporins and their complexes were tested using the paper disc diffusion method [17]. The chosen strains were $\mathrm{G}(+)$ Staphylococcus aureus ATCC 25923 and $\mathrm{G}(-)$ Escherichia coli ATCC 11775, Pseudomonas aeruginosa ATCC 27853, Klebsiella pneumoniae ATCC 23357, Salmonella enteritidis CDC 64, and Bacillus subtilis ATCC 6051. The liquid medium containing the bacterial subcultures was autoclaved for $20 \mathrm{~min}$ at $121^{\circ} \mathrm{C}$ before inoculation. The bacteria were then cultured for $24 \mathrm{~h}$ at $36^{\circ} \mathrm{C}$ in an incubator. Muller Hinton broth was used for preparing basal media for the bioassay of the organisms. Nutrient agar was poured onto a plate and allowed to solidify. The test compounds in DMSO solutions $\left(5 \times 10^{-2} \mathrm{M}\right)$ were added dropwise $(10 \mu \mathrm{L})$ to a $5 \mathrm{~mm}$ diameter filter paper disc placed at the centre of each agar plate. The plates were then kept at $5^{\circ} \mathrm{C}$ for $1 \mathrm{~h}$ then transferred to an incubator maintained at $36^{\circ} \mathrm{C}$. The width of the growth inhibition zone around the disc was measured after $24 \mathrm{~h}$ incubation. Four replicates were made for each treatment and the values recordedare the mean average.
2.3. Preparation of the Complexes. The complexes were prepared by mixing clear solutions of the appropriate cephalosporin sodium salt $(1 \mathrm{mmol})$ and $\mathrm{NiCl}_{2} \cdot 6 \mathrm{H}_{2} \mathrm{O}$ metal salt: $(1 \mathrm{mmol})$ in distilled water $\left(10 \mathrm{~cm}^{3}\right)$ and sulfathiazole $(1 \mathrm{mmol})$ in EtOH $\left(10 \mathrm{~cm}^{3}\right)$. The reaction mixture was then stirred at room temperature for $4 \mathrm{~h}$. and green precipitates formed. The precipitated complexes were filtered off, washed with water, $\mathrm{MeOH}$ and ether, and dried under reduced pressure at room temperature. Complexes were purified by recrystallization from dimethylsulfoxide/water mixture. The purity of the compounds was checked by TLC using silica gel-G as an adsorbent. Yields: $65-70 \%$.

\section{Results and Discussion}

The results of elemental analyses $(\mathrm{C}, \mathrm{H}, \mathrm{N}, \mathrm{S}, \mathrm{Cl}$, and $\mathrm{Ni}$ content) are in good agreement with those calculated for the molecular formula of the prepared complexes (Table 1). All the complexes are green colored, air, and moisture stable amorphous solids, which decompose without melting. They are almost insoluble in water and other common organic solvents such as $\mathrm{MeOH}, \mathrm{EtOH}$, benzene, hexane, acetone, chloroform, acetonitrile, and ether but soluble in DMSO. The insolubility of the complexes suggests that they are polymeric compounds [18].

Thermograms of the hydrated metal complexes, $\left[\mathrm{Ni}\left(\mathrm{L}_{1}\right)\right.$ $\left.(\mathrm{stz})\left(\mathrm{H}_{2} \mathrm{O}\right)\right]$ and $\left[\mathrm{Ni}\left(\mathrm{L}_{4}\right)(\mathrm{stz})\left(\mathrm{H}_{2} \mathrm{O}\right)\right]$, indicate endothermic decompositions in the $150-180^{\circ} \mathrm{C}$ range due to the loss of one molecule of coordinated water with a found mass loss of 2.46 and $2.34 \%$ (calcd. 2.29 and $2.08 \%$ ), respectively [18, 19]. Thermal analysis for the cefepime complex $\left[\mathrm{Ni}\left(\mathrm{L}_{5}\right)(\mathrm{stz})\right] \mathrm{Cl}$ displays two stages of weight loss. The first decomposition process that occurs at about $387^{\circ} \mathrm{C}$ could be assigned to the loss of one chlorine atom with a found mass loss of $4.62 \%$ (calcd. $4.27 \%$ ). It can be seen that the complex began to decompose exothermically at ca. $420^{\circ} \mathrm{C}$, and the decomposition was completed at ca. $520^{\circ} \mathrm{C}$ leaving out $\mathrm{NiO}$ as a residue with a found mass loss of 9,52\% (calcd. 8.99\%).

Molar conductance values measured in DMSO at room temperature $\left(10^{-3} \mathrm{M}\right.$ solution) indicated that the complexes have lower values $\left(13-17 \Omega^{-1} \mathrm{~cm}^{-2} \mathrm{~mol}^{-1}\right.$ ) indicating their nonelectrolyte nature of these chelates [20] and that the sulfathiazole anion is coordinated to the metal. The only exception was $\left[\mathrm{Ni}\left(\mathrm{L}_{5}\right)(\mathrm{stz})\right] \mathrm{Cl}$, which showed higher value $\left(38 \Omega^{-1} \mathrm{~cm}^{-2} \mathrm{~mol}^{-1}\right.$ ) acting as $1: 1$ electrolyte in this solvent indicating the ionic nature of this chelate. According to elemental analysis, there is one chlorine atom for each nickel ion. The complex is slightly soluble in water. In order to decide whether the chlorine was bounded ionically or covalently, a small amount of a complex sample was dispersed in distilled hot water and filtered. $\mathrm{AgNO}_{3}$ testing of the filtrates gave a precipitate of $\mathrm{AgCl}$. This qualitative chlorine test implies that in $\left[\mathrm{Ni}\left(\mathrm{L}_{5}\right)(\right.$ stz $\left.)\right] \mathrm{Cl}$ complex, chlorine is bounded to the metal ionically. Hence, complexation gives a cationic complex with accompanying chloride ion in the form of counter anion. 
<smiles>Cc1nnc(SCC2=C(C(=O)ON)N3C(=O)C(NC(=O)Cn4cnnn4)C3SC2)s1</smiles>

$\mathrm{L}_{1}=$ cefazolin<smiles>CO/N=C(/C(=O)NC1C(=O)N2C(C(N)=O)=C(COC(C)=O)CSC12)c1csc(N)n1</smiles>

$\mathrm{L}_{3}=$ cefotaxime<smiles>CO/C=N/C(=O)C(=O)NC1C(=O)N2C(C(=O)[O-])=C(C[N+]3(C)CCCC3)CSC12</smiles>

$\mathrm{L}_{5}=$ cefepime<smiles>CC(=O)OCC1=C(C(=O)O)N2C(=O)C(NC(=O)Cc3cccs3)C2SC1</smiles>

$\mathrm{L}_{2}=$ cephalothin<smiles>CO/N=C(\C(=O)NC1C(=O)N2C(C(=O)ON)=C(CSc3nc(=O)c(O)nn3C)CSC12)c1csc(N)n1</smiles>

$\mathrm{L}_{4}=$ ceftriaxone

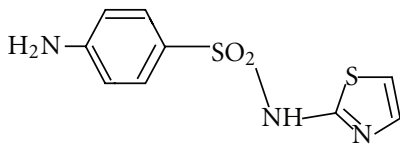

Hstz $=$ sulfathiazole

FIGURE 1: The structure of the ligands.

TABLE 1: Elemental analyses for the nickel(II) complexes.

\begin{tabular}{|c|c|c|c|c|c|c|}
\hline \multirow[t]{2}{*}{ Compound } & \multicolumn{6}{|c|}{ Found (Calcd.) \% } \\
\hline & $\mathrm{C}$ & $\mathrm{N}$ & $\mathrm{H}$ & $S$ & $\mathrm{Cl}$ & $\mathrm{Ni}$ \\
\hline$\left[\mathrm{Ni}\left(\mathrm{L}_{1}\right)(\mathrm{stz})\left(\mathrm{H}_{2} \mathrm{O}\right)\right]$ & 35.5 & 19.5 & 2.3 & 20.1 & & 7.2 \\
\hline$\left[\mathrm{Ni}\left(\mathrm{C}_{23} \mathrm{H}_{24} \mathrm{~N}_{11} \mathrm{O}_{7} \mathrm{~S}_{5}\right)\right]$ & $(35.2)$ & $(19.6)$ & (3.1) & $(20.4)$ & & $(7.5)$ \\
\hline$\left[\mathrm{Ni}\left(\mathrm{L}_{2}\right)(\mathrm{stz})\right]$ & 40.1 & 9.7 & 3.0 & 17.5 & & 8.1 \\
\hline$\left[\mathrm{Ni}\left(\mathrm{C}_{25} \mathrm{H}_{28} \mathrm{~N}_{5} \mathrm{O}_{10} \mathrm{~S}_{4}\right)\right]$ & $(40.3)$ & $(9.4)$ & $(3.8)$ & $(17.2)$ & & $(7.9)$ \\
\hline$\left[\mathrm{Ni}\left(\mathrm{L}_{3}\right)(\mathrm{stz})\right]$ & 39.5 & 14.2 & 3.3 & 17.1 & & 7.5 \\
\hline$\left[\mathrm{Ni}\left(\mathrm{C}_{25} \mathrm{H}_{25} \mathrm{~N}_{8} \mathrm{O}_{9} \mathrm{~S}_{4}\right]\right.$ & $(39.1)$ & $(14.6)$ & (3.3) & $(16.7)$ & & $(7.6)$ \\
\hline$\left[\mathrm{Ni}\left(\mathrm{L}_{4}\right)(\mathrm{stz})\left(\mathrm{H}_{2} \mathrm{O}\right)\right]$ & 37.3 & 17.7 & 2.8 & 18.1 & & 6.4 \\
\hline$\left[\mathrm{Ni}\left(\mathrm{C}_{27} \mathrm{H}_{25} \mathrm{~N}_{11} \mathrm{O}_{9} \mathrm{~S}_{5}\right)\right]$ & $(37.4)$ & $(17.8)$ & $(2.9)$ & $(18.5)$ & & $(6.8)$ \\
\hline$\left[\mathrm{Ni}\left(\mathrm{L}_{5}\right)(\mathrm{stz})\right] \mathrm{Cl}$ & 40.8 & 15.0 & 3.7 & 15.8 & 4.7 & 7.3 \\
\hline$\left[\mathrm{Ni}\left(\mathrm{C}_{28} \mathrm{H}_{34} \mathrm{~N}_{9} \mathrm{O}_{7} \mathrm{~S}_{4}\right)\right] \mathrm{Cl}$ & $(40.5)$ & $(15.2)$ & $(4.1)$ & $(15.4)$ & $(4.3)$ & $(7.1)$ \\
\hline
\end{tabular}

3.1. Infrared Spectra. The IR spectra of cephalosporins and their complexes are similar, and the main features are recorded in Table 2. Generally the ring carbonyl absorption frequency will be shifted to higher wavenumbers as the ring becomes more strained. The cephalosporins showed a strong absorption at $1730-1780 \mathrm{~cm}^{-1}$ lactam $(\mathrm{C}=\mathrm{O})$ stretching. This band shifted to lower frequency in the metal complexes. The amide $(\mathrm{C}=\mathrm{O})$ band is unshifted in the complexes compared to the free ligands (Figure 2). Given the significant shifts in the lactam $\mathrm{C}=\mathrm{O}$ bands in the complexes, we 
TABLE 2: IR spectral data of the drugs and the complexes $\left(\mathrm{cm}^{-1}\right)$.

\begin{tabular}{|c|c|c|c|c|c|c|c|}
\hline & $\nu \mathrm{C}=\mathrm{O}$ & $\nu \mathrm{C}=\mathrm{O}$ & $\nu \mathrm{COO}$ & $\nu \mathrm{COO}$ & $\Delta v$ & $\nu \mathrm{C}=\mathrm{N}$ & $\nu \mathrm{Ni}-\mathrm{N}$ \\
\hline Compound & Lactam & Amide & Asymm. & Symm & & & \\
\hline Cefazolin & 1765 & 1650 & 1600 & 1380 & 220 & & \\
\hline$\left[\mathrm{Ni}\left(\mathrm{L}_{1}\right)(\mathrm{stz})\left(\mathrm{H}_{2} \mathrm{O}\right)\right]$ & 1749 & 1650 & 1580 & 1370 & 210 & & 425 \\
\hline Cephalothin & 1730 & 1650 & 1620 & 1400 & 220 & & \\
\hline$\left[\mathrm{Ni}\left(\mathrm{L}_{2}\right)(\mathrm{stz})\right]$ & 1715 & 1650 & 1610 & 1390 & 220 & & 430 \\
\hline Cefotaxime & 1780 & 1640 & 1600 & 1375 & 225 & 1610 & \\
\hline$\left[\mathrm{Ni}\left(\mathrm{L}_{3}\right)(\mathrm{stz})\right]$ & 1750 & 1640 & 1590 & 1370 & 220 & 1605 & 426 \\
\hline Ceftriaxone & 1774 & 1667 & 1610 & 1400 & 210 & 1610 & \\
\hline$\left[\mathrm{Ni}\left(\mathrm{L}_{4}\right)(\mathrm{stz})\left(\mathrm{H}_{2} \mathrm{O}\right)\right]$ & 1755 & 1661 & 1600 & 1385 & 215 & 1610 & 430 \\
\hline Cefepime & 1770 & 1650 & 1600 & 1390 & 210 & 1600 & \\
\hline$\left[\mathrm{Ni}\left(\mathrm{L}_{5}\right)(\mathrm{stz})\right] \mathrm{Cl}$ & 1740 & 1650 & 1590 & 1380 & 210 & 1590 & 415 \\
\hline
\end{tabular}

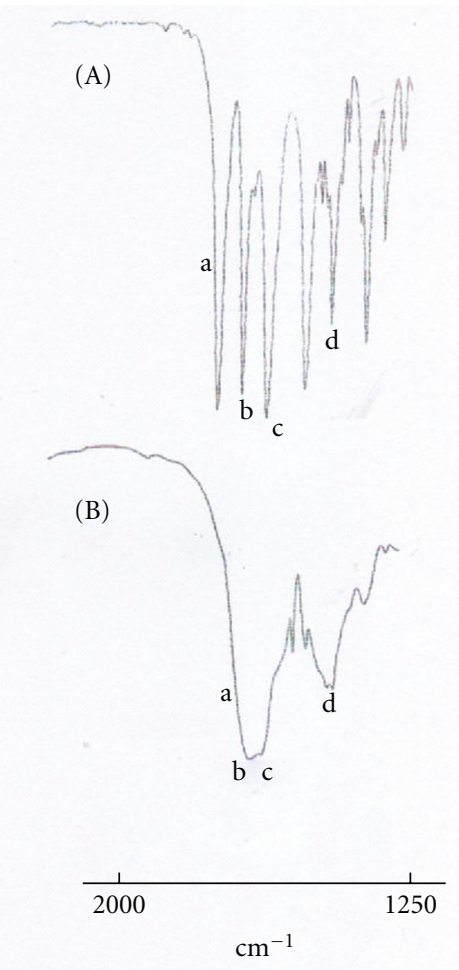

FIGURE 2: Infrared spectra of cephalothin (A) and $\left[\mathrm{Ni}\left(\mathrm{L}_{2}\right)(\mathrm{stz})\right]$ (B) in the solid state. Stretching CO lactam (a), stretching CO amide (b), asymmetric COO stretching (c), and symmetric $\mathrm{COO}$ stretching $(\mathrm{d})$.

suggest that coordination of the cephalosporin ligands occurs through the oxygen atom from the lactam rather than the amide carbonyl groups.

The band at $1600-1620 \mathrm{~cm}^{-1}$ corresponding to the carboxylate asymmetrical stretching of the free ligands is shifted $\left(10-20 \mathrm{~cm}^{-1}\right)$ to lower wavenumbers in the spectra of the complexes, indicating coordination through that group. The remaining carboxylate band, namely, $v_{\text {sym }}(\mathrm{COO})$, formerly at around $1400 \mathrm{~cm}^{-1}$, also changes as a result of coordination. A carboxylate ligand can bind to the metal atom either as a monodentate or a bidentate ligand, giving changes in the relative positions of the asymmetric and symmetric stretching vibrations [21, 22]. The IR spectra of the complexes give a separation value of $>200 \mathrm{~cm}^{-1}$ suggesting monodentate bonding for the carboxylate group.

The presence of $v(\mathrm{Ni}-\mathrm{N})$ stretching vibrations in the $410-430 \mathrm{~cm}^{-1}$ range for the complexes (absent in the free ligands) provides evidence that the sulfathiazole and cephalosporin moieties are bonded to the metal through the nitrogen atoms. Evidence of the N-thiazole interaction arises from the red shifts of the band assigned in the free sulfa drug to the thiazole ring vibrations (from $1550 \mathrm{~cm}^{-1}$ in the sulfathiazole to $1500 \mathrm{~cm}^{-1}$ in the complex) together with a marked intensity reduction. The bands at 3320 and $3280 \mathrm{~cm}^{-1}$, assigned to the $\nu_{\text {as }}(\mathrm{N}-\mathrm{H})$ and $\nu_{s}(\mathrm{~N}-\mathrm{H})$ vibrations, respectively, of the $\mathrm{NH}_{2}$ group are slightly shifted in the cefotaxime, ceftriaxone, and cefepime nickel(II) complexes.

The coordination of the tetrazole or $-\mathrm{NH}_{2}$ groups to the metal are not the only explanation of these absorption bands; alternatively, the $\mathrm{N}$ atom of the $\mathrm{CONH}$ and $\mathrm{C}=\mathrm{N}-$ $\mathrm{OCH}_{3}$ groups (when corresponding) could coordinate to the metal; however, steric constraints would probably prevent coordination of these $\mathrm{N}$ atoms along with the COO and lactam $\mathrm{CO}$ groups. Furthermore, the $\mathrm{C}=\mathrm{N}$ stretching vibration of the $\mathrm{C}=\mathrm{N}-\mathrm{OCH}_{3}$ residue, observed in free cefotaxime, ceftriaxone, and cefepime at $1600-1610 \mathrm{~cm}^{-1}$, either does not shift or shows a slight shift in all complexes, indicating that these groups are not involved in coordination. The usual modes of Hstz ligand are also present. As expected, the bands at 1310,1150 , and $560 \mathrm{~cm}^{-1}$ attributed to an $\mathrm{O}=\mathrm{S}=\mathrm{O}$ remain unchanged with respect to those of the ligand.

3.2. Magnetic Measurements. From the molar magnetic susceptibility values, corrected magnetic moments were calculated using Pascal's constants. The cefazolin and ceftriaxone nickel(II) complexes have magnetic moment values in the 3.02-3.12 BM range, which are expected for systems with two unpaired electrons with no metal-metal interactions. They are within the range 2.9-3.3 consistent with their octahedral configuration around the $\mathrm{Ni}(\mathrm{II})$ ion. Nickel(II) $\left(\mathrm{d}^{8}\right)$ ion, 
being a non-Krammer's ion, EPR spectra, is observable, generally at low temperatures. However, there are very few reports in the literature about the study of this $\mathrm{d}^{8}$ ion at room temperature. The $\mathrm{g}$ value is isotropic and close to 2.2 [23-25]. EPR spectra of powdered samples of abovementioned complexes were obtained at room temperature. They showed the same signals, a broad strong one at $3280 \mathrm{G}$ with $g=2.14$ and a linewidth of $200-430 \mathrm{G}$ and a weak one at $2460 \mathrm{G}$ with $\mathrm{g}=2.85$ and a linewidth of $110 \mathrm{G}$ suggesting that the mentioned complexes have similar structure. There was no evidence of fine structure due to ${ }^{61} \mathrm{Ni}$ nuclei $(1.19 \%$ natural abundance, $I=3 / 2$ ). On the other hand, the cephalothin, cefotaxime, and cefepime nickel(II) complexes have magnetic moments in the 3.6-3.8 BM range, which are higher than the values expected for octahedral geometry and consistent with the values expected for nickel(II) high spin pseudotetrahedral complexes [23].

3.3. Electronic Spectra. The UV-Vis spectra of the complexes in DMSO solutions present absorption maxima attributable to the ligands. A band at $250-270 \mathrm{~nm}$ is assigned to $\pi \rightarrow$ $\pi^{*}$ transitions, while an intraligand band at $290-320 \mathrm{~nm}$ is related to the $\pi \rightarrow \pi^{*}$ transitions within the heterocyclic moieties [26, 27]. The band in the $360-380 \mathrm{~nm}$ region is ascribed to an intraligand transition of the $n \rightarrow \pi^{*}$ type in accordance with the literature data for transitions due to sulphur atoms $[26,28]$. The fact that the bands due to sulphur atoms are not shifted suggests that this atom is not involved in coordination. A long-term UV-Vis study was carried out to verify the stability of new complexes in DMSO solution. Compared with ligands, it is significant to note that the absorption wavelengths of new complexes hardly varied for up to 1 month, meaning that new complexes were stable in DMSO solution.

Different geometries of nickel(II) have quite different spectra in the visible and near-infrared portions of the spectrum. The absorptions in this region are due to $\mathrm{d}$ $\mathrm{d}$ transitions and are quite weak compared to typical ultraviolet spectra. The electronic spectra of the complexes in solid state show almost similar features as in DMSO solution. The electronic spectra of $\left[\mathrm{Ni}\left(\mathrm{L}_{1}\right)(\mathrm{stz})\left(\mathrm{H}_{2} \mathrm{O}\right)\right]$ and $\left[\mathrm{Ni}\left(\mathrm{L}_{4}\right)(\mathrm{stz})\left(\mathrm{H}_{2} \mathrm{O}\right)\right]$ showed $\mathrm{d}-\mathrm{d}$ bands in the region $10,417-$ $10,526,15,500-16,010$ and $24,100-25,000 \mathrm{~cm}^{-1}$, assigned to ${ }^{3} \mathrm{~A}_{2 g}(\mathrm{~F}) \rightarrow{ }^{3} \mathrm{~T}_{2 g}(\mathrm{~F})\left(\nu_{1}\right),{ }^{3} \mathrm{~A}_{2 g}(\mathrm{~F}) \rightarrow{ }^{3} \mathrm{~T}_{1 g}(\mathrm{~F})\left(\nu_{2}\right)$ and ${ }^{3} \mathrm{~A}_{2 g}(\mathrm{~F})$ $\rightarrow{ }^{3} \mathrm{~T}_{1 g}(\mathrm{P})\left(v_{3}\right)$ transitions, respectively. The calculated molar absorptivities of these absorptions are typically less than 10. The values of magnetic moments (3.02 and 3.12 B.M.), the spin-orbit coupling constants $(\lambda=-175$ and $-267 \mathrm{~cm}^{-1}$ ), and the calculated ligand field parameters of Dq $=1,042$ and $1,053 \mathrm{~cm}^{-1}, \mathrm{~B}=557$ and $629 \mathrm{~cm}^{-1}$, and $\beta=0.53$ and 0.60 indicating covalent complexes are also consistent with the octahedral geometry. The bands observed at ca. $12,500 \mathrm{~cm}^{-1}$ can be assigned to spin forbidden transitions to singlet levels originated by ${ }^{1} \mathrm{D}$ and ${ }^{1} \mathrm{G}$ splitting.

Tetrahedral nickel(II) typically has a similar spectrum but shifted to lower energies. The electronic spectra of the light green nickel(II) complexes $\left[\mathrm{Ni}\left(\mathrm{L}_{2}\right)(\mathrm{stz})\right],\left[\mathrm{Ni}\left(\mathrm{L}_{3}\right)(\mathrm{stz})\right]$, and $\left[\mathrm{Ni}\left(\mathrm{L}_{5}\right)(\mathrm{stz})\right] \mathrm{Cl}$ are consistent with tetrahedral geometry showing one band at about $13,900-14,000 \mathrm{~cm}^{-1}$ assignable to ${ }^{3} \mathrm{~T}_{1}(\mathrm{~F}) \rightarrow{ }^{3} \mathrm{~T}_{1}(\mathrm{P})\left(\nu_{3}\right)$ transition and a band at $22,222 \mathrm{~cm}^{-1}$ assignable to charge-transfer $[28,29]$. The calculated molar absorptivities are of about 100 .

3.4. Coordination Sites. In our case, the antibiotics have several potential donor atoms that might be involved in coordination with the nickel ions forming polymers. The assumption that the coordination of cephalothin, cefotaxime, and cefepime occurs through the carboxylate, lactam carbonyl group, and aminothiazolyl moiety (or Sthiophene group in the cephalothin ligand) seems likely that they behave as tridentate ligands. The multidentate chelation would require some kind of polymeric structure in which the ligand bridges different metal centres, since these atoms would be incapable of chelating a single metal due to geometric constraints. For instance, it is feasible that the nickel ions in the $\left[\mathrm{Ni}\left(\mathrm{L}_{5}\right)(\mathrm{stz})\right]^{+}$cation complex containing coordinated stz anion are four-coordinate. Although, it would not be appropriate to predict precisely the structure of these complexes, a structure may tentatively be proposed. Figure 3 shows a suggested structure of $[\mathrm{Ni} \text { (cefepime)(stz) }]^{+}$ cation complex.

On the other hand, the coordination of cefazolin and ceftriaxone may occur through the carboxylate, lactam carbonyl, and two N-heterocyclic moieties; thus it is possible that they behave as monoanionic tetradentate ligands [13, 15]. It has been reported that deprotonated sulfathiazole, stz, coordinates through the $\mathrm{N}$-thiazole moiety [7-10]. We have attempted to grow single crystals of the metal chelates but in no case have we had any success, due to their insolubility in common organic solvents. These studies represent a contribution to future crystallographic analyses, which are complicated by the difficulties in obtaining X-ray quality crystals of cephalosporins complexes.

3.5. Microbiological Screening. Preliminary screening for antimicrobial activities of the stock solutions of the ligand and metal complexes was performed qualitatively using the disc diffusion assay. In vitro antimicrobial activities were measured from the diameter of clear inhibition zones caused by samples against the same bacteria and under the identical experimental conditions. As assessed by colour, the complexes remain intact during biological testing. In order to clarify role of In order to clarify role of DMSO, sulfathiazole and nickel(II) chloride salt in the biological screening, separate studies were carried out with the solutions alone of DMSO, sulfathiazole, and the free metal salt, and they showed no significant activity against any bacterial strains. The antibacterial activities of the complexes were better than those of both the Hstz and the starting metal salt. These provided reasons to believe that antibacterial activities of the complexes synthesized do not correlate with the toxicity of them against the bacterial tested.

The results are shown in Table 3, where it can be appreciated that except cefepime complex in most cases the antimicrobial activity of complexes was similar or less than the activity of pure antibiotics. The cefazolin $\left[\mathrm{Ni}\left(\mathrm{L}_{1}\right)(\mathrm{stz}) \mathrm{H}_{2} \mathrm{O}\right]$ 


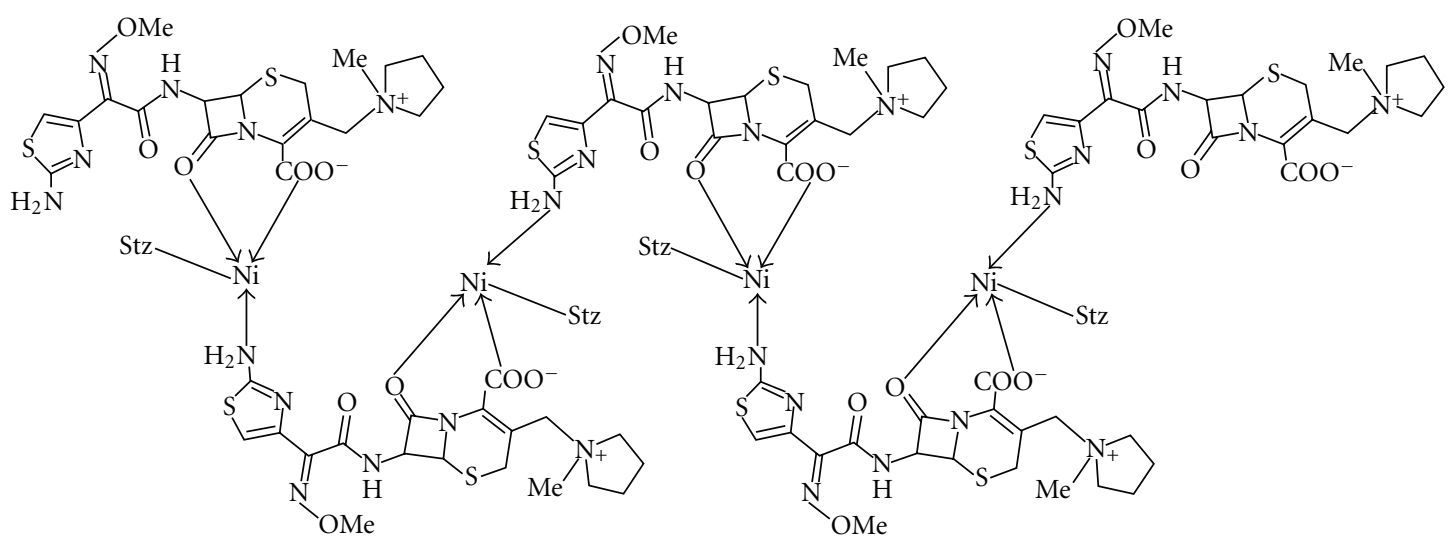

FIGURe 3: Suggested structure of $\left[\mathrm{Ni}\left(\mathrm{L}_{5}\right)(\mathrm{stz})\right]^{+}$cation complex.

TABle 3: Antibacterial activity of the drugs and the complexes.

\begin{tabular}{|c|c|c|c|c|c|c|}
\hline \multirow{2}{*}{ Compound } & \multicolumn{6}{|c|}{ Zone of inhibition $(\mathrm{mm})$} \\
\hline & E.C. & S.E. & P.A. & S.A & K.P. & B.S. \\
\hline Cefazolin & $33.0 \pm 1.5$ & $36.0 \pm 1.0$ & $0.0 \pm 0.0$ & $34.0 \pm 1.5$ & $35.0 \pm 0.5$ & $57.0 \pm 2.0$ \\
\hline$\left[\mathrm{Ni}\left(\mathrm{L}_{1}\right)(\mathrm{stz})\left(\mathrm{H}_{2} \mathrm{O}\right)\right]$ & $20.0 \pm 2.5$ & $18.0 \pm 0.0$ & $0.0 \pm 0.0$ & $27.0 \pm 1.0$ & $23.0 \pm 1.0$ & $37.0 \pm 1.0$ \\
\hline Cephalothin & $19.0 \pm 0.5$ & $29.0 \pm 1.0$ & $0.0 \pm 0.0$ & $25.0 \pm 1.0$ & $33.0 \pm 1.5$ & $60.0 \pm 0.5$ \\
\hline$\left[\mathrm{Ni}\left(\mathrm{L}_{2}\right)(\mathrm{stz})\right]$ & $10.0 \pm 0.0$ & $21.0 \pm 0.5$ & $0.0 \pm 0.0$ & $27.0 \pm 0.5$ & $20.0 \pm 1.0$ & $33.0 \pm 1.0$ \\
\hline Cefotaxime & $40.0 \pm 1.5$ & $34.0 \pm 0.0$ & $23.0 \pm 1.0$ & $18.0 \pm 2.0$ & $39.0 \pm 0.5$ & $35.0 \pm 1.0$ \\
\hline$\left[\mathrm{Ni}\left(\mathrm{L}_{3}\right)(\mathrm{stz})\right]$ & $31.0 \pm 1.0$ & $37.0 \pm 0.5$ & $17.0 \pm 0.0$ & $13.0 \pm 0.5$ & $24.0 \pm 0.5$ & $37.0 \pm 0.5$ \\
\hline Ceftriaxone & $33.0 \pm 0.5$ & $38.0 \pm 1.0$ & $35.0 \pm 2.0$ & $25.0 \pm 1.0$ & $40.0 \pm 1.0$ & $43.0 \pm 0.5$ \\
\hline$\left[\mathrm{Ni}\left(\mathrm{L}_{4}\right)(\mathrm{stz})\left(\mathrm{H}_{2} \mathrm{O}\right)\right]$ & $35.0 \pm 1.0$ & $32.0 \pm 0.0$ & $22.0 \pm 0.5$ & $15.0 \pm 0.5$ & $28.0 \pm 1.0$ & $35.0 \pm 1.5$ \\
\hline Cefepime & $13.0 \pm 2.0$ & $25.0 \pm 1.5$ & $0.0 \pm 0.0$ & $0.0 \pm 0.0$ & $25.0 \pm 2.0$ & $30.0 \pm 1.0$ \\
\hline$\left[\mathrm{Ni}\left(\mathrm{L}_{5}\right)(\mathrm{stz})\right] \mathrm{Cl}$ & $30.0 \pm 1.5$ & $33.0 \pm 0.5$ & $19.0 \pm 1.0$ & $15.0 \pm 1.0$ & $28.0 \pm 0.0$ & $35.0 \pm 0.5$ \\
\hline Sulfathiazole & $8.0 \pm 1.0$ & $7.0 \pm 0.5$ & $7.0 \pm 0.5$ & $6.0 \pm 0.0$ & $7.0 \pm 1.0$ & $8.0 \pm 1.5$ \\
\hline
\end{tabular}

E.C., Escherichia coli ATCC 35939; S.E., Salmonella enteritidis ATCC 497; P.A., Pseudomonas aeruginosa ATCC 10145; S.A., Staphylococcus aureus ATCC 25923 ; K.P., Klebsiella pneumonia ATCC 10031; B.S., Bacillus subtilis ATCC 6051. Values are the mean \pm Standard deviation of the mean.

complex showed lower bactericidal activity than the free ligand against all tested bacteria. The complexed cefotaxime $\left[\mathrm{Ni}\left(\mathrm{L}_{3}\right)(\right.$ stz $\left.)\right]$ showed better activity against Salmonella enteritidis and Bacillus subtilis than the uncomplexed cefotaxime, while ceftriaxone and cephalothin complexes showed better activity against Escherichia coli and Staphylococcus aureus than the free antibiotics, respectively.

The cefepime adduct, at difference of all the others, shows better antibacterial activity than that of the free ligand against all tested bacteria. The cefepime $\left[\mathrm{Ni}\left(\mathrm{L}_{5}\right)(\mathrm{stz})\right] \mathrm{Cl}$ complex is only electrolyte that showed better activity than free cefepime against all bacteria strains, including against $P$. aeruginosa and $S$. aureus where cefepime is inactive. The cefepime complex activity could be slightly higher because of the different structure of cefepime compared to other cephalosporins tested (it has a zwitterionic structure possessing the pyrrolidinium ring). Antibacterial activity of mixed-ligand nickel ion complexes depends mainly on the type of cephalosporin used, the metal ion, and the type of microorganism.
It is known that chelation tends to make the ligand to act as more powerful and potent bacterial agent [29-35]. However, when using $\beta$-lactam ligands, the complexation significantly reduces the antimicrobial activity of the ligands. Considering that metal coordination generally involves the $\beta$-lactam $\mathrm{C}=\mathrm{O}$, a significant increase in the lability of the $\beta$-lactam ring could be anticipated; however, as sometimes happens the antimicrobial activity of $\beta$-lactam complexes is higher. The results in Table 3 can be understood considering that the enzyme probably serves primarily to hold catalytic groups or the substrate in the proper positions and is possible to expect that metal complexes of $\beta$-lactam antibiotics may change the stereochemistry required in solvolytic reactions on an enzyme surface. The results may highlight that the activity of the compounds is most probably related to their conformational adaptability, depending on the size and nature of the metal complexes and the geometrical constraints induced by intramolecular $\mathrm{H}$ bonds. Thus, the activity of $\beta$-lactam complexes compared to $\beta$-lactams (Table 3) may reflect a different mechanistic pathway by 
which the various metal complexes and the $\beta$-lactams react with the PBP active sites to achieve formation of a stable PBP-inhibitor adduct. The level of resistance to $\beta$-lactam complexes is determined by the amount, nature, and kinetic properties of the PBPs.

\section{Acknowledgments}

Authors are grateful to the Comisión de Investigación at the Universidad de Oriente for providing financial support. Authors are also grateful to Lic. Erasto Bastardo for the elemental analyses.

\section{References}

[1] A. A. Mederios, "Evolution and dissemination of beta-lactamases accelerated by generations of beta-lactam antibiotics," Clinical Infectious Diseases, vol. 24, no. 1, supplement, pp. S19S45, 1997.

[2] H. Bello, M. Dominguez, G. Gonzalez et al., "In vitro activities of ampicillin, sulbactam and a combination of ampicillin and sulbactam against isolates of Acinetobacter calcoaceticusAcinetobacter baumannii complex isolated in Chile between 1990 and 1998," Journal of Antimicrobial Chemotherapy, vol. 45, no. 5, pp. 712-713, 2000.

[3] H. F. Chambers and M. Sachdeva, "Binding of $\beta$-lactam antibiotics to penicillin-binding proteins in methicillin-resistant Staphylococcus aureus," Journal of Infectious Diseases, vol. 161, no. 6, pp. 1170-1176, 1990.

[4] C. J. Hackbarth, T. Kocagoz, S. Kocagoz, and H. F. Chambers, "Point mutations in Staphylococcus aureus PBP 2 gene affect penicillin- binding kinetics and are associated with resistance," Antimicrobial Agents and Chemotherapy, vol. 39, no. 1, pp. 103-106, 1995.

[5] T. Kamimura, Y. Matsumoto, N. Okada et al., "Ceftizoxime (FK 749), a new parenteral cephalosporin: in vitro and in vivo antibacterial activities," Antimicrobial Agents and Chemotherapy, vol. 16, no. 5, pp. 540-548, 1979.

[6] K. P. Fu and H. C. Neu, "Antibacterial activity of ceftizoxime, a $\beta$-lactamase-stable cephalosporin," Antimicrobial Agents and Chemotherapy, vol. 17, no. 4, pp. 583-590, 1980.

[7] J. Casanova, G. Alzuet, S. Ferrer, J. Borras, S. Garcia-Granda, and E. Perez-Carreno, "Metal complexes of sulfanilamide derivatives. Crystal structure of [ $\mathrm{Zn}$ (sulfathiazole)2] $\cdot \mathrm{H}_{2} \mathrm{O}$," Journal of Inorganic Biochemistry, vol. 51, no. 4, pp. 689-699, 1993.

[8] J. Casanova, G. Alzuet, J. Borras, J. Latorre, M. Sanau, and S. Garcia-Granda, "Coordination behavior of sulfathiazole. Crystal structure of [Cu (sulfathiazole)(py)3Cl] superoxide dismutase activity," Journal of Inorganic Biochemistry, vol. 60, no. 3, pp. 219-230, 1995.

[9] J. Casanova, G. Alzuet, J. Borras, J. Timoneda, S. GarciaGranda, and I. Candano- Gonzalez, "Coordination behavior of sulfathiazole. Crystal structure of dichloro- disulfathiazole ethanol $\mathrm{Cu}(\mathrm{II})$ complex. Superoxide dismutase activity," Journal of Inorganic Biochemistry, vol. 56, no. 2, pp. 65-76, 1994.

[10] J. Casanova, G. Alzuet, J. Borrás, and O. Carugo, "Crystal structures and superoxide dismutase mimetic activity of $\left[\mathrm{CuL}_{2}(\mathrm{Him})_{2}\right] \cdot \mathrm{MeOH}$ and $\left[\mathrm{CuL}_{2}(\mathrm{mim})_{2}\right] \cdot \mathrm{H}_{2} \mathrm{O} \quad[\mathrm{HL}=4-$ amino-N-(thiazol-2-yl)benzenesulfonamide, Him = imidazole, mim = N-methylimidazole]," Journal of the Chemical Society-Dalton Transactions, no. 11, pp. 2239-2244, 1996.
[11] J. R. Anacona and H. Rodriguez, "Metalloantibiotics: synthesis and antibacterial activity of cefepime metal complexes," Journal of Coordination Chemistry, vol. 62, no. 13, pp. 22122219, 2009.

[12] J. R. Anacona and G. Da Silva, "Synthesis and antibacterial activity of cefotaxime metal complexes," Journal of the Chilean Chemical Society, vol. 50, no. 2, pp. 447-450, 2005.

[13] J. R. Anacona and P. Alvarez, "Synthesis and antibacterial activity of metal complexes of cefazolin," Transition Metal Chemistry, vol. 27, no. 8, pp. 856-860, 2002.

[14] J. R. Anacona and J. Serrano, "Synthesis and antibacterial activity of metal complexes of cephalothin," Journal of Coordination Chemistry, vol. 56, no. 4, pp. 313-320, 2003.

[15] J. R. Anacona and A. Rodriguez, "Synthesis and antibacterial activity of ceftriaxone metal complexes," Transition Metal Chemistry, vol. 30, no. 7, pp. 897-901, 2005.

[16] J. R. Anacona and L. Brito, "In vitro cytotoxicity and antibacterial activities of cephalosporin Tin(II) complexes," Latin American Journal of Pharmacy, vol. 30, no. 1, p. 172, 2011.

[17] D. Liu and K. Kwasniewska, "An improved agar plate method for rapid assessment of chemical inhibition to microbial populations," Bulletin of Environmental Contamination and Toxicology, vol. 27, no. 1, pp. 289-294, 1981.

[18] S. A. Khan, N. Nishat, S. Parveen, and R. Rasool, "Preparation, spectral and biological investigation of formaldehyde-based ligand containing piperazine moiety and its various polymer metal complexes," Spectrochimica Acta Part A, vol. 81, pp. 290395, 2011.

[19] A. V. Nikolaev, V. A. Logvinenko, and L. T. Myachina, Thermal Analysis, vol. 2, Academic Press, New York, NY, USA, 1969.

[20] W. J. Geary, "The use of conductivity measurements in organic solvents for the characterisation of coordination compounds," Coordination Chemistry Reviews, vol. 7, no. 1, pp. 81-122, 1971.

[21] K. Nakamoto, Infrared and Raman Spectra of Inorganic and Coordination Compounds, John Wiley \& Sons, New York, NY, USA, 4th edition, 1986.

[22] G. Socrates, Infrared Characteristic Group Frequencies, John Wiley \& Sons, London, UK, 1980.

[23] K. A. R. Salib, A. A. Saleh, S. Abu El-Wafa, and H. F. O. El-Shafiy, "Preparation and characterization of novel asymmetrical Schiff-base ligands derived from 2-methyl-7-formyl8-hydroxyquinoline and their metal complexes," Journal of Coordination Chemistry, vol. 56, no. 4, pp. 283-298, 2003.

[24] R. Srinivasan, I. Sougandi, R. Venkatesan, and P. Sambasiva Rao, "Synthesis and room temperature single crystal EPR studies of a dinickel complex having an $\mathrm{Ni}^{2}(\mu$ phenoxide $2^{2+}$ unit supported by a macrocyclic ligand environment $\left[\mathrm{Ni}^{2}(\mathrm{~L})^{2}\left(\mathrm{OClO}^{3}\right)^{2}\right][\mathrm{L}=2$-[(4-methyl-pyridin-2ylimino)-methyl]-phenol]," Proceedings of the Indian Academy of Sciences, vol. 115, no. 2, pp. 91-102, 2003.

[25] E. Mosiniewicz-Szablewska, A. Ślawska-Waniewska, K. Światek, N. Nedelko, and M. Golebiewski, "Magnetic properties of Ni-complexes in a hydrazone structure," Physica Status Solidi (A) Applied Research, vol. 196, no. 1, pp. 213-216, 2003.

[26] G. C. Franchini, A. Giusti, C. Preti, L. Tassi, and P. Zannini, "Coordinating ability of methylpiperidine dithiocarbamates towards platinum group metals," Polyhedron, vol. 4, no. 9, pp. 1553-1558, 1985.

[27] C. C. Hadjikostas, G. A. Katsoulos, and S. K. Shakhatreh, "Synthesis and spectral studies of some new palladium(II) and 
platinum(II) dithiocarbimato complexes. Reactions of bases with the corresponding N-alkyldithiocarbamates," Inorganica Chimica Acta, vol. 133, no. 1, pp. 129-132, 1987.

[28] M. Castillo, J. J. Criado, B. Macias, and M. V. Vaquero, "Chemistry of dithiocarbamate derivatives of amino acids. I. Study of some dithiocarbamate derivatives of linear $\alpha$-amino acids and their nickel(II) complexes," Inorganica Chimica Acta, vol. 124, no. 3, pp. 127-132, 1986.

[29] D. X. West, A. K. El-Sawaf, and G. A. Bain, "Metal complexes of N(4)-substituted analogs of the antiviral drug methisazone 1-methylisatin thiosemicarbazone," Transition Metal Chemistry, vol. 23, pp. 1-6, 1998.

[30] O. A. El-Gammal, G. A. El-Reash, and S. F. Ahmed, "Structural, spectral, thermal and biological studies on 2-oxo$\mathrm{N}^{\prime}$-((4-oxo-4H-chromen-3-yl)methylene)-2-(phenylamino) acetohydrazide $\left(\mathrm{H}_{2} \mathrm{~L}\right)$ and its metal complexes," Journal of Molecular Structure, vol. 1007, pp. 1-10, 2012.

[31] S. A. Sadeek, H. W. El-Shwiniy, W. A. Zordok, and E. Kotb, "Spectroscopic studies, thermal analyses and biological evaluation of new $\mathrm{V}(\mathrm{IV}), \mathrm{Zr}(\mathrm{IV})$ and $\mathrm{U}(\mathrm{VI})$ moxifloxacin complexes," Journal of Molecular Structure, vol. 192, p. 1006, 2011.

[32] J. R. Anacona and C. Toledo, "Synthesis and antibacterial activity of metal complexes of ciprofloxacin," Transition Metal Chemistry, vol. 26, no. 1-2, pp. 228-231, 2001.

[33] I. Turel, L. Golic, P. Bukovec, and M. Gubina, "Antibacterial tests of bismuth (III) -quinolone (Ciprofloxacin, cf) compounds against helicobacter pylori and some other bacteria," Journal of Inorganic Biochemistry, vol. 71, pp. 53-60, 1998.

[34] I. Turel, I. Leban, and N. Bukovec, "Crystal structure and characterization of the bismuth(III) compound with quinolone family member (ciprofloxacin). Antibacterial study," Journal of Inorganic Biochemistry, vol. 66, no. 4, pp. 241-245, 1997.

[35] H. F. A. El-Halim, G. G. Mohamed, M. M. I. El-Dessouky, and W. H. Mahm, "Ligational behaviour of lomefloxacin drug towards $\mathrm{Cr}$ (III), $\mathrm{Mn}$ (II), $\mathrm{Fe}(\mathrm{III}), \mathrm{Co}(\mathrm{II}), \mathrm{Ni}(\mathrm{II}), \mathrm{Cu}(\mathrm{II}), \mathrm{Zn}$ (II), $\mathrm{Th}(\mathrm{IV})$ and UO2(VI) ions: synthesis, structural characterization and biological activity studies," Spectrochimica Acta A, vol. 82, pp. 8-19, 2011. 


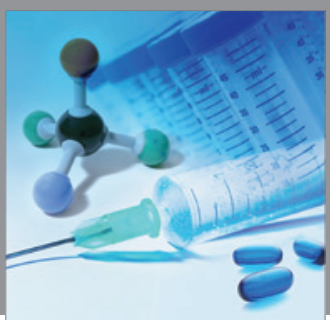

International Journal of

Medicinal Chemistry

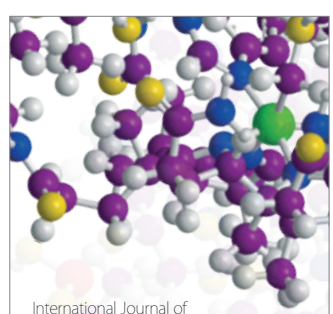

Carbohydrate Chemistry

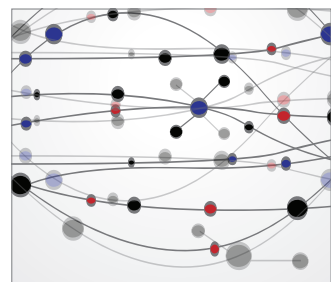

The Scientific World Journal
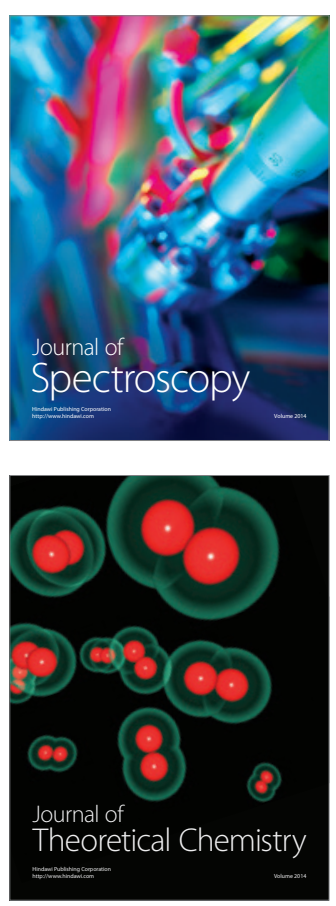
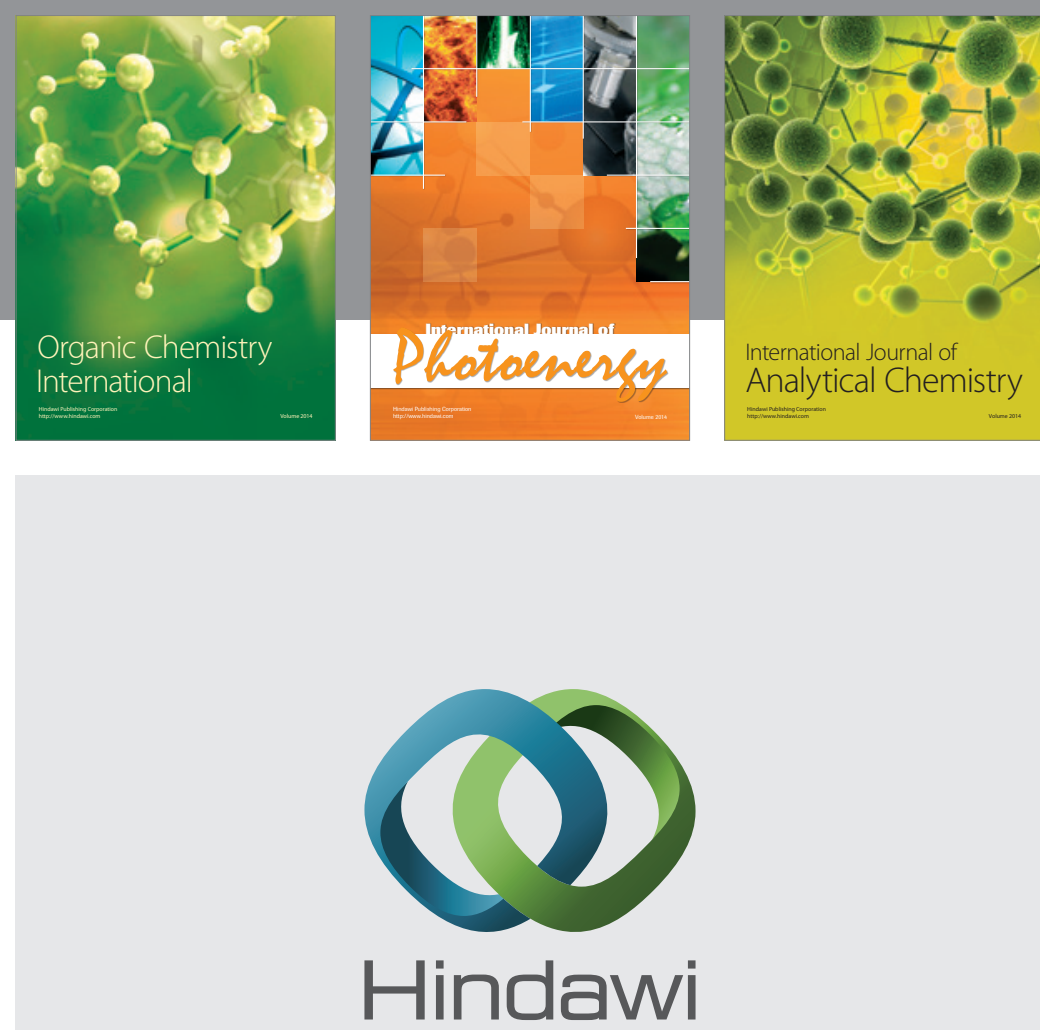

Submit your manuscripts at

http://www.hindawi.com
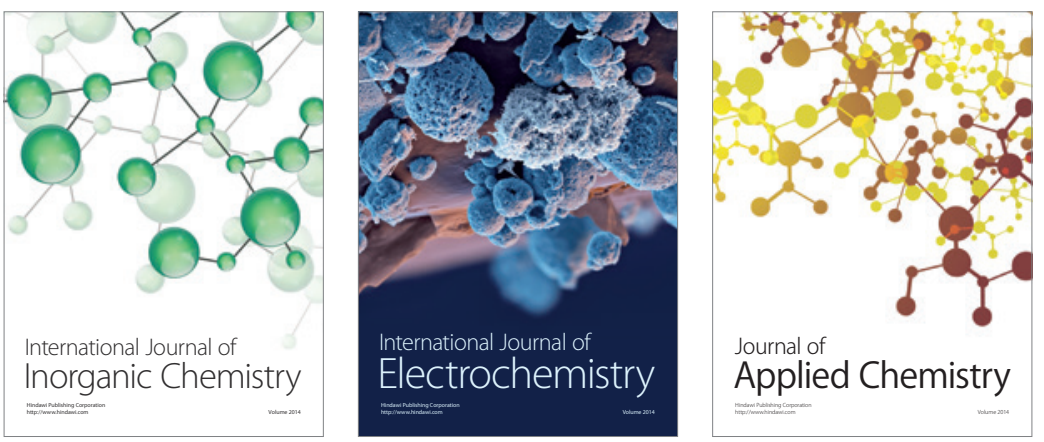

Journal of

Applied Chemistry
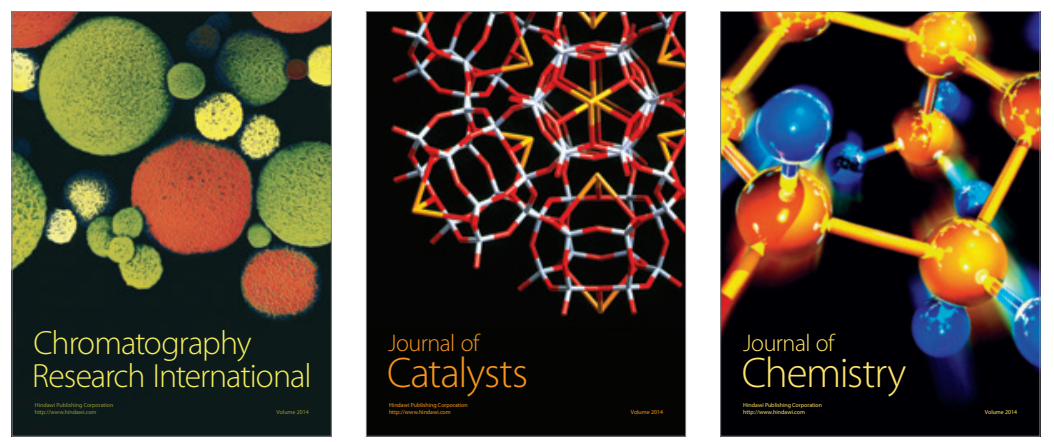
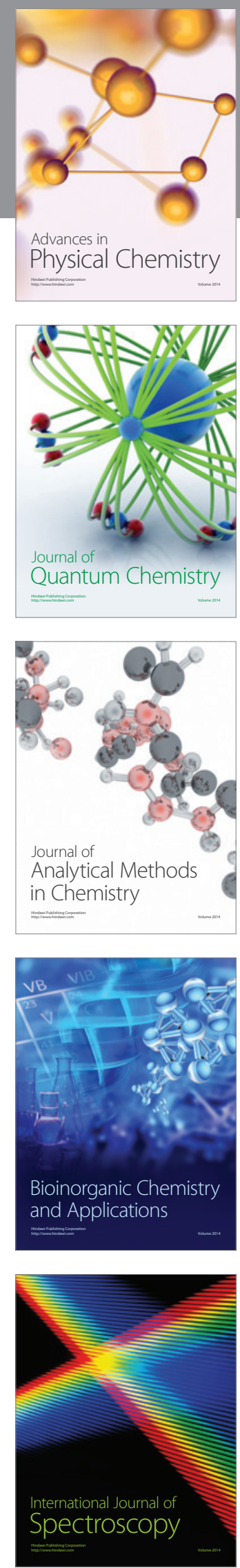